\title{
REPLY TO ELEANOR HELMS ON FAITH VERSUS REASON IN KIERKEGAARD
}

\author{
Merold Westphal
}

\begin{abstract}
Two reasons are given for speaking of "reason" even where Kierkegaard's pseudonym, Climacus, speaks of "understanding." First, we are dealing with a significant contribution to a centuries-old discussion of an issue that goes by the name of "faith and reason." Second, whereas Kant and Hegel sharply distinguish mere understanding from reason, no such distinction is at work in Kierkegaard's text. At issue is the quite different distinction of unaided human reason and divine revelation. It is not just any notion of reason that is the target of Kierkegaard's critique, but an autonomous reason, independent of revelation, that claims hegemony over biblical faith in both its popular and academic forms. This hegemony expresses itself in both outright rejection of and radical reinterpretation of elements of biblical faith.
\end{abstract}

Eleanor Helms thinks I overemphasize the "against reason" dimension of Kierkegaard's ${ }^{1}$ thought. ${ }^{2}$ Part of the argument is that Climacus speaks instead of faith as "against understanding." I have not overlooked this, but I think there are two good reasons to use the language of reason for this dimension of Kierkegaard's thought, whether he speaks of "understanding," "reason," "recollection," or "speculation." From the earliest times in which Christian thinkers sought to come to terms with Greek philosophy (which they found to be like fire-useful but dangerous) there has been an ongoing discussion of the question of faith and reason-in just those terms. That is the classical name for this classical conversation. Under that heading, the topic remains a major theme in contemporary philosophy of religion. The question concerns the relation of what theologians sometimes call special revelation, speech acts by God to or through partic-

${ }^{1}$ Just to be clear, when I attribute ideas to Kierkegaard I mean simply that our friend Soren is the one who, by inscribing them, presented them to us for our consideration, whether in his own name or pseudonymously. I make no claim about what "the historical Soren" (heaven help us) "really thought" or about the significance of any particular pseudonym.

${ }^{2}$ Helms, "On Climacus's 'Against Reason' Thesis." She is referring to my book, Kierkegaard's Concept of Faith. 
ular individuals at particular times and places, including the inscription of Scripture, to reason as the standard, "factory-installed" equipment of the human intellect, operating without dependence on divine revelation. Kierkegaard's writings represent a complex and many-faceted contribution to this conversation that could easily be missed if we were to follow Climacus's usage instead of "faith and reason."

Kierkegaard is not immediately concerned with the patristic and medieval positions, but instead with the distinctively modern view of the matter. What I call the Enlightenment project in the philosophy of religion is nicely summed up in Kant's title, Religion Within the Limits of Reason Alone. I take Spinoza, Kant, and Hegel to be the most powerful expressions of this view in the seventeenth, eighteenth, and nineteenth centuries, respectively. It holds the following theses:

1. Philosophical reason is universal. It can and does rise above any conditioning by what is particular and contingent so as to be presuppositionless, unconditioned, objective, neutral, and "non-sectarian." It is the famous "view from nowhere" or, perhaps, from everywhere.

2. As such, reason has a rightful hegemony over religion, and philosophy over theology, whether that be the beliefs of the laity in the pew or the scholars in the academy. This is the rightful subordination of the particular to the universal. (N.B. The hegemony claim is a corollary of the universality claim. It filters out what is merely local and thus not authoritative for all.)

3. This hegemony takes two forms: outright rejection or radical reinterpretation of the religion of the laity and the theologians. The line between rejection and reinterpretation is not absolute. It is hard to know which category best fits the naturalistic pantheism, the moralistic deism, or the sociological pantheism with which Spinoza, Kant, and Hegel seek to replace the personalist theism of biblical religion.

The problem with this project, of course, is that each of the resultant philosophical theologies is mutually incompatible with both of the other two. What presents itself as pure or universal Reason turns out to be as thoroughly sectarian as, say, Judaism, Christianity, and Islam or Protestant, Catholic, and Jew. ${ }^{4}$ As a postmodern thinker, Kierkegaard would welcome this insight and argue that the "scandal of particularity" hangs over these and similar philosophical theologies every bit as much as over the "religions of the book." There being no a priori privilege derived from a spurious universality, these religious orthodoxies meet their would-be

${ }^{3}$ I am told that David Swenson, a native speaker, has pointed out that ordinary Danish, like ordinary English, does not distinguish understanding from reason in the way in which Kant and Hegel do, and that he preferred "reason" as the translation of Forstanden, rather than "understanding," for reasons similar to those I have given.

${ }^{4}$ Herberg, Protestant, Catholic, Jew. 
philosophical tutors on a level playing field. Each is a particularity claiming universal significance.

We might note in passing that postmodern philosophies challenge the universality thesis and emphasize the conditioned and local nature of any view of reason substantive enough to have anything interesting to say about matters social, moral, and religious. Each variety of reason is conditioned by and relative to the quite particular traditions (Gadamer), language games (Wittgenstein, Derrida), and social practices (Foucault) in which it is embedded. ${ }^{5}$

But some postmodern philosophers retain the hegemony thesis without making clear what the ground for this might be. Thus in "Phenomenology and Theology," Heidegger repeatedly-nine times-asserts that it is the task of phenomenological philosophy to "correct" theology; ${ }^{6}$ and Derrida reinterprets theistic themes beyond recognition. Thus, for Derrida, God is the name for the fact "that language has started without us"; $;$ or the name of "the absolute singularity of the other"; 8 or "the name of the possibility I have of keeping a secret that is visible from the interior but not from the exterior." ${ }^{\prime 9}$ At this point radical reinterpretation becomes outright rejection, as was already the case with Spinoza's (in)famous Deus sive natura.

So, my first reason for saying "reason" even where Climacus says "understanding" is because of Kierkegaard's contribution to this longstanding locus in the philosophy of religion.

My second reason relates to another point Helms makes. She notes that both Kant and Hegel make a sharp distinction between understanding (Verstand) and reason (Vernunft). I don't see Kierkegaard making a similar distinction. But what I think is beyond dispute is that when Kierkegaard (or Climacus in particular) discusses the relation of biblical faith to the human intellect, he does not mean what they mean by "understanding." For Kant and Hegel,

1. Understanding is the intellect's cognition of finite and conditioned reality as found in common sense being-in-the-world and the natural sciences.

2. Understanding tries but fails to give us metaphysical knowledge, contrary to the assumption of medieval and pre-Kantian modern philosophers.

3. Reason-as the faculty of the unconditioned, of totality, of what is absolute-is the metaphysical dimension of the intellect.

\footnotetext{
${ }^{5}$ See, for example, Gadamer, Truth and Method; Wittgenstein, Philosophical Investigations; Derrida, "How to Avoid Speaking"; and Foucault, Power/Knowledge.

${ }^{6}$ Heidegger, "Phenomenology and Theology."

${ }^{7}$ Derrida, "How to Avoid Speaking," 99.

${ }^{8}$ Derrida, The Gift of Death, 67.

${ }^{9}$ Derrida, The Gift of Death, 108.
} 
Of course, Kant argues that its metaphysical aspirations collapse as well, lapsing into paralogism and antinomy, while Hegel argues that although this does happen, speculative reason can overcome this obstacle and give us the metaphysical knowledge that is the horizon and touchstone for all other knowledge, including religious knowledge.

In a crucial passage in his Lesser Logic, Hegel distinguishes three modes of the human intellect: (1) understanding, (2) reason in its negative, dialectical moment, and (3) reason in its positive, speculative moment. ${ }^{10}$ We might distinguish the dialectical and speculative moments as the deconstructive and reconstructive powers of reason. Although it has a dialectical moment, Hegel's philosophy is regularly identified as speculation by both him and Kierkegaard. (Incidentally, since Kierkegaard affirms the dialectical moment but not the speculative, he, rather than Hegel, can be said to be the dialectical philosopher.) It is abundantly clear that Climacus is not addressing understanding in this fairly technical sense when he is discussing the relation of divine revelation to merely human thought. He has in mind the Hegelian version of "reason-within-the-limits-of-reasonalone," the one that flies the flag of speculative reason, with its claims of universality and hegemony.

I have perhaps placed more weight on the significance of "understanding" in Climacus than Helms has, and for this reason. It makes it possible to be quite specific about what faith is "against" when it is against reason. Helms notes that I warn that "we should not latch onto just any possible meaning of the phrase 'against reason' and attribute it to Climacus." ${ }^{11}$ My view, and I think this is clear in Kierkegaard's Concept of Faith, is that the reason Kierkegaard presents in various writings as in opposition to faith is that of which Hegel's system is a prime example, a reason that makes the hegemony claim on the basis of the universality claim. It is not every conception of reason, nor is it just any conception that happens to be at hand. It is quite specific, substantive, and not merely formal.

Helms writes, "Either Kierkegaard means to criticize unfounded claims about reason-i.e., contingent claims, non-a priori assumptions-or he criticizes reason [Fornuft / Vernunft] in its universal, transcendental sense as it was used by Kant and Hegel." I see no either/or here. My claim is that the universal, transcendental sense used by Kant and Hegel is the expression of unfounded, contingent, socially situated claims, not an alternative to them. As a Christian postmodernist, Kierkegaard rejects both the universality and the hegemony claims. Sometimes he writes as a Christian and speaks from the standpoint of a faith, seeing in the hegemony claim not a "new and improved," perhaps updated version of orthodox Christianity but a wolf dressed in sheep's clothing. Other times, especially in pseudonymous writings, he poses as an outside observer, and argues: This is faith (a particular, biblical faith), and this is reason

\footnotetext{
${ }^{10}$ Hegel, The Encyclopedia Logic, §§79-82.

${ }^{11}$ Westphal, Kierkegaard's Concept of Faith, 224.
} 
(a particular tradition with numerous sects going back at least to Plato and dominant in Enlightenment thinkers). Anyone should be able to see that the two are incompatible. The biblical notion of divine revelation and the notion of philosophy's hegemony over theology are, I believe, "essentially opposed" (Helms's phrase) both in Kierkegaard and in fact. Either/ Or. This view, by the way, is transformative. It means that Christianity is essentially counter-cultural and that constantinianism is always a pyrrhic victory.

This is not to say that there is no place for some other version of reason, presumably a humbler version, in the life of faith. That is why one of my chapters on Fear and Trembling can be entitled "Faith as the Teleological Suspension of Reason." A teleological suspension is an Aufhebung in Hegel's sense. It is not an extermination, but taking something that pretends to be self-grounding and absolute and subordinating it to a position of dependence in the context of a larger whole whose horizon and touchstone it is not. That is why, in Fear and Trembling, the ethical, a Hegelian version of practical reason, is not abolished but given a relative normative significance.

While Kierkegaard leaves open a space for a subordinate role of reason in the life of faith, he does not develop it very much because he sees the threat of the hegemony thesis and its practice to be a far more pressing matter. More than a few versions of the hegemony thesis, in either its modern or postmodern versions, are alive and well when the discussion turns to matters theological. My sense is that in popular culture it is the Hegelian ethical (practical reason) as portrayed in Fear and Trembling that presupposes a hegemony that threatens biblical faith, and that in the academy it is theoretical reason where the problem is found. I am not sure our situation is as different from Kierkegaard's as Helms seems to think.

Fordham University

\section{References}

Derrida, Jacques. 1992. "How to Avoid Speaking: Denial." In Derrida and Negative Theology, edited by Harold Coward and Toby Foshay (SUNY Press).

Derrida, Jacques. 2008. The Gift of Death, 2nd ed. Translated by David Wills (University of Chicago Press).

Foucault, Michael. 1980. Power/Knowledge. Edited by Colin Gordon (Pantheon Books).

Gadamer, Hans-Georg. 1991. Truth and Method, 2nd ed. revised (Crossroad).

Hegel, G. W. F. 1991. The Encyclopedia Logic. Translated by T. F. Geraets, W. A. Suchting, and H. S. Harris (Hackett).

Heidegger, Martin. 1998. “Phenomenology and Theology.” In Pathmarks, edited by William McNeill (Cambridge University Press).

https://doi.org/10.1017/СBO9780511812637 
Helms, Eleanor. 2017. “On Climacus's 'Against Reason' Thesis: A Challenge to Westphal." Faith and Philosophy 34: 471-488.

https://doi.org/10.5840/faithphil2017102687

Herberg, Will. 1955. Protestant, Catholic, Jew (University of Chicago Press).

Westphal, Merold. 2014. Kierkegaard's Concept of Faith (Eerdmans).

Wittgenstein, Ludwig. 1958. Philosophical Investigations, 2nd ed. (Basil Blackwell). 